\title{
Effect of nitrate and nitrite on sulfide production by two thermophilic, sulfate-reducing enrichments from an oil field in the North Sea
}

\section{Krista M. Kaster • Alexander Grigoriyan •}

Gary Jenneman • Gerrit Voordouw

Published online: 22 March 2007

(C) Springer-Verlag 2007

\section{Erratum to: Appl Microbial Biotechnol}

\section{DOI: $10.1007 / \mathrm{s00253-006-0796-5}$}

Unfortunately, the name of the third author was rendered incorrectly. His correct name is given above.

The online version of the original article can be found at: http://dx.doi. org/10.1007/s00253-006-0796-5.

\section{K. M. Kaster}

International Research Institute of Stavanger (IRIS),

Akvamiljø, Mekjarvik 12,

N4070 Randaberg, Norway

\section{A. Grigoriyan $\cdot$ G. Voordouw $(\bowtie)$}

Department of Biological Sciences, University of Calgary,

2500 University Drive, NW,

Calgary, Alberta T2N IN4, Canada

e-mail: voordouw@ucalgary.ca

\section{G. Jenneman}

ConocoPhillips, $224 \mathrm{~GB}$,

Bartlesville, OK 74004, USA 